УдК 81'42:32]:81'37

https://doi.org/10.33989/2524-2490.2021.34.250161

VIKTORIIA KRAVCHENKO

ORCID 0000-0002-3837-3203

(Полтава) (Poltava)

Place of work: Poltava V.G. Korolenko National Pedagogical University

Country: Ukraine

Email: dr.kravchenkoviki@gmail.com

HALYNA SOSOI

ORCID0000-0003-0507-8109

(Полтава) (Poltava)

Place of work: Poltava V.G. Korolenko National Pedagogical University Country:

Ukraine

Email: soykagaga@gmail.com

SVITLANA DEINEKA

ORCID 0000-0003-2551-9813

(Полтава) (Poltava)

Place of work: Poltava V.G. Korolenko National Pedagogical University Country:

Ukraine

Email: svetlana_dei@i.ua

\title{
NEW VISION OF CONCEPT EUROPE (A LINGUISTIC PERSPECTIVE)
}

У статті представлено дослідження концепту ЄВРОПА, проведене $з$ позицї когнітивної лінгвістики. Концепт ЄВРОПА вважають понятійним квантом структурованих знань, що складається з різних смислів. Стаття аналізуе концепт ЕВРОПА з лінгвістичної точки зору, що дозволило розкрити ряд специфічних ознак його семантики, отримати більш об'ємне та різнобічне уявлення про нього шляхом побудови когнітивних схем, за якими він реалізуеться, а також виявити базові метафоричні моделі, у терлінах яких осмислюеться евроінтеграційна реальність. Залучення методів концептуального аналізу дозволяе представляти досліжжуваний концепт у вигляді певної фреймової моделі, особливим способом організованої концептуальної схеми. За допомогою концептуальної моделі предметного фрейму розкрито когнітивну диналіку розгортання концепту в евроінтеграційному дискурсі.

Ключові слова: лінгвоконцепт; дискурс; політичний дискурс; концепт ЕВРОПА; семантика; метафорична модель; ідеологія.

The topicality of this work is due to the focus of modern linguistic research on the study of new types of discourse, including political, which are in the process of formation. The European integration discourse, which is based on new conceptual principles, is important from the point of view of studying the linguistic mechanisms of constructing newly formed ideologies. In this regard, it is important to reveal the linguistic representation of the concept EUROPE, which plays a structural role in the discourse and, acquiring a new semantic content, expands its functioning as one of the key cultural concepts.

The study aims to identify the means of representation of the concept of EUROPE in the English-language political discourse on European integration, considered in terms of their semantic-cognitive and linguistic-pragmatic features.

The political relationship modernization, the modern society democratization, and the political movement of the integration processes led to the mental space changes. The problem of the concept EUROPE and the European vector changes are taken under special research in different scientific spheres: political science, sociology, humanitarians and cognitive linguistics, etc. The correlation of language and ideology, language and social reality is taken under the research attention in modern linguistics, precisely in the sphere of political discourse analysis. 
One of the peculiarities of this problem is the fact that the new subjects for linguistics study are formed under the influence of social changes. These subjects demand special consideration. The European integration's processes, which form the complex of important sociolinguistics' consequences, are also giving rise to the new kinds of political discourse, which is widely accessible due to the development of the Internet.

The question about the nature and the function of the concept EUROPE leads us to the understanding of the "European identity", Enlargement, the future, and the past of Europe.

The new ideology of the UNITED EUROPE that is formed with the help of European integration political discourse has a complex structure of several substantial blocs. The analysed material has proved that the main blocks are "common values", "European integration" and "enlargement". So let us study these blocs thoroughly focusing attention on the ways of lexical means that represent certain contexts. My research goals and strategies consist in checking understanding of the changing role of Europe (or EU) in English political discourse (or English European integration discourse). English political discourse analysis: the message through links, bonds, keywords and repetitions, metaphors, catchphrases, visual images, moral appeals, slogans, and other symbolic devices. Working out an algorithm for evaluation of the EU image in political discourse, based on the obtained data.

Semantic and cognitive features of the concept EUROPE representation in English European integration discourse were revealed through building cognitive schemes that disclose its realisation. My research also determines basic metaphorical models in terms of which the reality of European integration is emphasized. Research on EU and Europe representation and their attributes, predicates, etc. in English political discourse, e.g., geographical features, political features, etc. with a special focus on a comparison of anti-Eastern and pro-European media. The usage of EU concepts among the newly-elected politicians and the presence/ absence of their proEuropean guidelines are tracing.

The central concept of NEW EUROPE that forms the new ideology is being got the deep metaphoric comprehension. If metaphors are not just stylistic ornaments, but a way of thinking, there is no reason why this potential should only be used to structure categories underlying certain abstract words, and why it should not show up the way we approach the complex scientific, political, and social issues of the world.

The cognitive content of the concept EUROPE, the conceptual scheme of which was based on the definition of Modern English explanatory dictionaries and the semantic analysis of lexicographic material allowed us to conclude the lexical representation of this concept.

In English dictionaries, the analyzed concept is represented by the lexemes as Europe, European, European Union, there is also synonymous word as ancient home, Europa, (the) Mediterranean world, the Low Countries.

Metaphor is an important factor that constitutes discourse. This is confirmed by modern studies of discourse, which are devoted to the analysis of its variants - advertising (Danesi, 2015), journalistic (Afrouzi, 2020), military (Lakoff, 1996), medical (Wilce, 2009), legal (Konstantinova, 2011), etc. For political discourse, the study of metaphorical models is also precisely important, because metaphors, according to political discourse study, are an important factor in political decision-making and, are considered as a means of analysing the state of public consciousness (Baranov \& Karaulov, 1994, p. 188-189; Filatenko, 2003, p. 5; Yavorska, 2002, p. 66).

The idea of conceptual metaphors was formed in Lakoff and Johnson work "Metaphors, we live by" (Lakoff, Johnson, 1980). Its main point consists of the fact that our activity in the world is conditioned by the conceptual system, and our conceptual system is metaphorical in point of fact. The idea of conceptual or basic metaphors lies in metaphorical terms that are general for all the members of society.

Follow Lakoff and Johnson closely and their cognitive metaphor theory I have analysed metaphor phrases that represent the Eurointegration discourse. I have marked out some metaphor models, which help us to comprehend the Eurointegration reality: building, transport and carrier, production, sports contest, plant etc.

The material of our study was English texts corpus based on the Internet sites of the European Union for the period of 2005 - 2020 years.

So I am going to illustrate the single unity structure by the examples from the metaphoric comprehensions of European base. 
In the metaphoric expressions as "The European Union - administrative machine of the world; Germany was the engine of integration" there is a metaphoric model "production": engine \machine productive mechanism \ production. Here "machine" is in the meaning of machine, a mechanism that fulfils the remaking function or even produces the new material (create the new world). So EU is a certain productive mechanism in the administrative sphere of construction the new world, as the integration is impossible without a certain mechanism. In the other example "engine" with its main connotation - the engine that set going a mechanism, makes it not static but dynamic. The certain changes in Germany (1989) - German unification - became the moving force of the Eurointegration.

The metaphor "carrier" belongs to the metaphor "journey" from the point of the participant activity - driving the new Europe: "The Conflict resolution is not the only impulse driving the new Europe; Sir John gave warning: the political consequences of pursuing the present course risk serious damage to the practical reality of collective defences in EU and to the future of the Euro-Atlantic relationship; Draft Nice Treaty takes European Union in wrong direction says New Europe; European Union treaties move the EU in wrong direction".

The metaphor "building" - "...offices and procedures under the EU roof <...;; Europe is creating some new kind of state" is closely connected with the metaphor "production".

The metaphor "flower" (plant) or "bouquet" was presented by the following examples "European culture is a "bouquet de fleurs". Together they are beautiful, but rose is still rose, and the tulipis still tulip. This must be preserved".

The metaphor "EUROPE IS ORCHESTRA" is represented in the Eurointegration discourse by the following examples - "Europe is the orchestra, but the violins are still violins. We must guarantee that each instrument has its own voice".

The heightened metaphorical nature of the discourse we study is quite natural because a new fragment of political reality is described and created with the help of metaphors in this discourse. And metaphor itself is a search, an attempt to go beyond the known experience of interaction with the world, based on knowledge, a projection of the studied area onto the unexplored or, in terms of the theory of conceptual metaphor, the expansion of the concepts of the source domain, resulting in the development of a new sphere - the target domain. Conceptual metaphors typically employ a more abstract concept as target and a more concrete or physical concept as their source (Kövecses, 2002). This circumstance provides the main functions of metaphor in political discourse: constructive as the function of understanding new political realities, and destructive - the function of destroying existing stereotypes of consciousness.

Thus, the range of Eurointegration metaphors reflects the different projects of our life substitute actions - the real sum upon creating the new society without wars, where the culture of each country will be saved. On the other hand, the global integration of European society, unification in the political structure, which will be peace guarantor, leads us out to the new understanding of NEW EUROPE and metaphoric comprehension of the concept EUROPE.

Understanding of the terms "Europe" and "EU" for Europeans was checked out (e.g., when they say "Europe", they'll never think of Moldova, Bulgaria or even Russia though geographically they are Europe). The age factor is under research: how the image of Europe depends on the age of the audience (e.g., youth magazines, papers read by adults and the aged).

Research on communicative strategies and tactics used in English European integration discourse that contribute to achieving the addresser's communicative aim - the integration of European citizens around idea of New Europe; determination of particular features of the concept EUROPE embodiment in European integration discourse with due regard for this discourse ideology through the opposition "one's selves" - "aliens". Due to this, the comparison of findings with those of other partners is held (e.g., non-EU countries and EU countries).

\section{REFERENCES}

Afrouzi, A. O. (2020). Social media and journalistic discourse analysis: 2019 Venezuelan presidential crisis. Discourse $\mathcal{E}$ Communication, 15, 1, 3-24. Retrieved from https://journals.sagepub.com/doi/10.1177/1750481320961660.

Baranov, A. N., \& Karaulov, Yu. N. (1994). Slovar russkikh politicheskikh metafor [Dictionary of Russian Political Metaphors]. RAS. Inst rus. lang. Moskva: Pomovsky and partners [in Russian].

Danesi, Marcel. (2015). Advertising Discourse. In TRACY Karen, IliE Cornelia \& SANDEL Todd (Eds.), The International Encyclopaedia of Language and Social Interaction, $1^{\text {st }}$ ed., Oxford: John Wiley \& Sons, Inc. Retrieved from https:/onlinelibrary.wiley.com/doi/pdf/10.1002/9781118611463.wbielsi137. 
Filatenko, I. O. (2003). Suchasna politychna metafora v rosiiskomovnomu hazetnomu spilkuvanni Ukrainy: kohnityono-prahmatychnyi opys [Modern political metaphor in Russian-language newspaper communication of Ukraine: cognitive-pragmatic description]. (Extended abstract of PhD diss.). Kyiv [in Ukrainian].

Konstantinova, M. V. (2011). Spetcifika pravovoi metafory v individualnoi leksike: (eksperimentalnoe issledovanie) [Specificity of legal metaphor in individual lexicon: (experimental research)]. (Extended abstract of PhD diss.). Kursk: Kursk. state un-t [in Russian].

Kövecses, Zoltán. (2002). Metaphor. A Practical Introduction, Oxford \& New York: Oxford University Press.

Lakoff, G., \& Johnson, M. (1980). Metaphors We Live By. Chicago, IL: Chicago University Press.

Lakoff, G. (1996). Moral Politics: What Conservatives Know That Liberals Don't. Chicago: University Chicago Press.

Wilce, James M. (2009). Medical Discourse. Department of Anthropology, Northern Arizona University, Flagstaff, Arizona.

Yavorska, G. M. (2002). Politychna rytoryka ta realii yevropeiskoi intehratsii. [Political rhetoric and the realities of European integration]. Viche [Chamber], 7, 66-71 [in Ukrainian].

\section{VIKTORIIA KRAVCHENKO, HALYNA SOSOI, SVITLANA DEINEKA \\ NEW VISION OF CONCEPT EUROPE (A LINGUISTIC PERSPECTIVE)}

This article presents a study of the concept EUROPE, done in the area of cognitive linguistics. The concept EUROPE is considered a conceptual quantum of structured knowledge, possessing of different meanings. The articleanalyzes the concept EUROPE from a linguistic point of view, which allowed to reveal a number of specific features of its semantics, to get a more comprehensive and diverse view of it by constructing cognitive schemes implementing concept EUROPE, as well as to identify basic metaphorical models. Involvement of methods of conceptual analysis allows to present the analised concept in the form of a certain conceptual model, a special way organized conceptual scheme. With the help of the conceptual model of the Subject frame the cognitive dynamics of the concept developmentin the European integration discourse is revealed.

Political metaphor is one of the most common and effective policy tools. The research material is characterized by the use of metaphors belonging to such basic types, which are related to the reference spheres as the sociomorphic sphere, the anthropomorphic sphere, the sphere of artifacts and the sphere of nature. Conceptual metaphors of European integration discourse use in their codes the conceptual fields "space", "travel", "movement", "construction", "work results", "family relations", "nature", "sports", "art", etc.

Key words: linguistic concept, discourse, political discourse, concept EUROPE, semantics, metaphorical model, ideology.

Отримано 27.03.2021 p. 